\title{
Is energy drink safe? A cross sectional study on the effects of energy drink on
}

\section{medical students from a medical school of Nepal}

\author{
Banerjee I1, Pugazhandhi B ${ }^{2}$, Banerjee ${ }^{3}$, Sathian B ${ }^{4}$, Nagpal PR ${ }^{5}$, Roy B ${ }^{6}$
}

${ }^{1}$ Assistant Professor, Department of Pharmacology, Padmashree Dr. D. Y. Patil Medical College, Ebene, Mauritius

${ }^{2}$ Assistant Professor, Department of Anatomy, Padmashree Dr. D. Y .Patil Medical College, Ebene, Mauritius

3 Post Doctorate Trainee, M.Ch Urology, SMS Medical College, Rajasthan, India

${ }^{4}$ Assistant Professor, Department of Community Medicine, Manipal College of Medical Sciences, Pokhara, Nepal.

5 Professor and Head, Department of Pharmacology, Padmashree Dr. D. Y. Patil Medical College, Ebene,

Mauritius

${ }^{6}$ Assistant Professor, Department of Physiology, Manipal College of Medical Sciences, Pokhara, Nepal.

\section{Chief Editor}

\section{Dr.Padam Simkhada}

Technical Editor

Dr. Nishida Chandrasekharan

Formatting Editor

Dr.Ram Lakhan
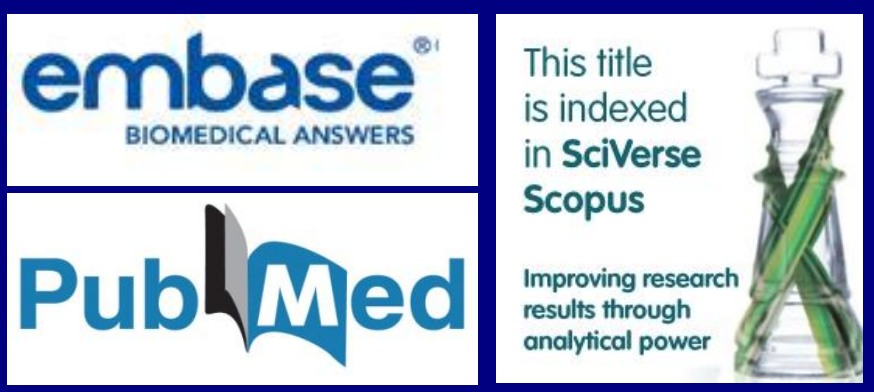

\section{Original Article}

Corresponding Author

Dr Indrajit Banerjee MD

Assistant Professor

Department of Pharmacology

Padmashree Dr.D.Y.Patil Medical College

3rd Floor Altima Building

Ebene, Cybercity, Mauritius

E-mail:indrajit18@gmail.com

\section{Abstract}

\section{Background}

Energy drinks that contain caffeine, taurine, vitamins, herbal supplements, sugar or sweeteners are marketed to improve energy, weight loss, stamina, athletic performance and concentration. Recently some of energy drink has been banned in different countries like Saudi Arabia. In Nepal none of the studies has been done to report the effect of energy drink on health. The main objective of the study was to find out the effect of energy drink on health of medical students.

\section{Materials and Methods}

It was a cross sectional questionnaire based study done at Manipal College of Medical Sciences, Pokhara, Nepal on November 2013.

Results:

Out of 206 students 202 completed the questionnaire completely and their responses were evaluated which gives an overall response rate of $98.05 \% \%$. Out of 202 students, $88(43.56 \%)$ students were found consuming energy drinks. 


\section{Energy drink consumption among medical students}

The research finding revealed that most of the students who consumed energy drink were male $58 \%$. Most of the students felt energetic after consuming energy drink. The majority of the students were from the second year $79.5 \%$. The majority of the students, $71.6 \%$ consumed $<5$ cans/week. Among the CNS manifestations students felt energetic, insomnia, euphoria, anxiety, dizziness, hallucination, headache and seizure disorder. Most of the students suffered from palpitation among the CVS manifestations. Other GIT and CVS Manifestations were discomfort, nausea, vomiting, diarrhoea, abdominal pain, constipation, weight loss and chest pain. ANS and miscellaneous manifestations were also seen among the students among which increased stamina, micturation, dry mouth, sweating, burning sensation in the throat, allergic reactions, breathlessness were noted by the students. Headache and insomnia was found more prevalent in males [OR 1.836 95\% (Cl 0.458, 7.367)] and [OR 1.214, $95 \%(\mathrm{Cl}$ $0.517,2.852)]$, respectively as compared to female students. However, in the case of GIT manifestations viz. abdominal pain and constipation revealed that it was more prevalent among male students [OR 2.292, $95 \%(\mathrm{Cl}(0.343,13.638)]$ and [OR 1.836, $95 \%(\mathrm{Cl} 0.458,7.367)]$.

\section{Conclusion}

It is concluded that energy drink gives energy and increases the stamina but it produces neurologic, psychiatric, cardiovascular and gastrointestinal complications on health. Further studies are required on the same field to find out its effect on health in Nepalese population.

Keywords: Energy drink, Nepal, medical students

\section{Background}

Energy drinks that contain caffeine, taurine, vitamins, herbal supplements, sugar or sweeteners are marketed to improve energy, weight loss, stamina, athletic performance and concentration. It may contain 80 to $300 \mathrm{mg}$ of caffeine. Adverse effects which have been reported with caffeine containing energy drink ${ }^{1}$ are insomnia, nervousness, headache, tachycardia, seizures and even case reports of caffeine associated deaths are reported ${ }^{2}$.

Medical students undergo a lot of stress during their course due to the massive course and curriculum. Recently some of energy drink has been banned in different countries like Saudi Arabia. They have prohibited advertising of any energy drinks or do advertising or promotional campaigns for any energy drink via any readable, audible or visible media or by any other means. They have banned energy drinks companies, their agents, distributors and marketing associations from sponsoring any sporting, social or cultural event, or taking any procedure leading to promotion and the free distribution of energy drinks to consumers of all age groups. Energy drinks has been banned for sale in restaurants and canteens in government facilities; education and health facilities; halls and public and private sports clubs. The factory owners and importers of energy drink should mention about the warning of the harmful effects in Arabic and English languages over the $\operatorname{tin}^{3}$. An occasional to a moderate consumption of these drinks has little risk for healthy adults. However, excessive consumption associated with negative consequences on health ${ }^{4}$. According to a study done at 16 countries of the European Union conducted by the European Food Safety Authority for energy drinks it was found that $68 \%$ of adolescents, $30 \%$ of adults, and $18 \%$ of children consumed energy drinks. The highest incidence were reported from Czech Republic where $82 \%$ of the adults and $40 \%$ of the children consumed energy drink ${ }^{5}$. In Nepal none of the studies has been done to report the effect of energy drink on health. This is the first study reported from Nepal. The main objective of the study will be to find out the effect of energy drink on health of medical students.

\section{Material and Methods}

\section{Study design:}

It is a cross sectional questionnaire based study done at Manipal College of Medical Sciences, Pokhara, Nepal on November 2013.

\section{Data collection:}

The collected data include socio-demographic details such as gender (male and female), nationality (Maldivian, Srilankan, Indian and Nepalese). Level of the student (1st year and $2^{\text {nd }}$ year), alcoholic (yes/no), smoker (yes/no), consumption of cans/week $(<5$ and $>5$ ). Different CNS manifestations like dizziness (yes/no), felling energetic( yes/no), euphoria( yes/no), headache( yes/no), insomnia( yes/no), prolonged sleep( yes/no), hallucination( yes/no), anxiety( yes/no), seizure (yes/no) were collected. GIT and CVS manifestations like nausea( yes/no), vomiting( yes/no), diarrhoea( yes/no), abdominal pain( yes/no) , constipation( yes/no), weight loss( yes/no), discomfort( yes/no), chest pain( yes/no) and palpitation( yes/no) were collected. Various ANS and miscellaneous manifestations viz. dry mouth( yes/no), sweating( yes/no), micturation( yes/no), breathlessness( yes/no), allergic reactions( yes/no), burning sensation of the throat( yes/no), increased stamina and good taste( yes/no) were considered for collection of data. The data was collected when the $1^{\text {st }}$ year student just joined the MBBS course, whereas for the $2^{\text {nd }}$ year student the data was collected after their $1^{\text {st }}$ MBBS university examination thus it can be assumed that the students were not under examination stress when the data was collected.

\section{Inclusion criteria:}

Out of 206 students 202 completed the questionnaire completely and their responses were evaluated which gives an overall response rate of $98.05 \% \%$. Among the 206 students 88 were found to be positive for consumption of energy drink were included in the study. 
Energy drink consumption among medical students only $13.6 \%$. The majority of the students were from the second year $79.5 \%$. Around $15.9 \%$ of the students were alcoholic and $6.8 \%$ were smokers. The majority of the students $71.6 \%$ consumed $<5$ cans/week (Table 1 ).

nts who didn't complete the questionnaire completely were excluded from the study. Prior to the data collection history was taken from the student and those students who were suffering from any medical illness were excluded from the study.

\section{Sample size calculation:}

For $95 \%$ confidence interval and, significance level $\alpha=5 \%$, $P=90 \%, Q=10 \%$, allowable error $=10 \%$ of $P$, required sample size was $266^{6}$. Prior to the study a pilot study was done in 10 students who consumes energy drink, it was found that $90 \%$ of the students were having insomnia. We got a sample of 206 students among which 88 students consumed energy drink.

\section{Outcome Variable:}

The main outcome variable was the most common clinical manifestations after consuming energy drink.

\section{Explanatory variables:}

The Socio demographic and energy drink consumption have been defined at individual level. Factors which were taken into consideration at individual level were gender (male and female) and number of cans of energy drink consumption per week.

\section{Ethical committee approval:}

The Research was conducted in accordance to latest version of the Declaration of Helsinki ${ }^{7}$.

Prior the study, ethical committee approval was taken from the institutional ethical committee, Manipal Teaching hospital, Pokhara, Nepal.

\section{Data management and statistical analysis:}

The data collected was analyzed using Excel 2003, R 2.8.0 Statistical Package for the Social Sciences (SPSS) for Windows Version 20.0 (SPSS Inc; Chicago, IL, USA) and EPI Info 3.5.1 Windows Version. chi square test was used to observe the difference between different variables and strength of the relationship with logistic regression. $p<0.05$ was considered as statistically significant. We calculated odds ratios and their $95 \% \mathrm{Cl}$.

\section{Result:}

\section{Socio demographic factors and energy drink consumption}

The research finding revealed that most of the students who consumed energy drink were male $58 \%$ and female were only $42 \%$. As per as the nationality is concerned most of the students were Nepalese $35.2 \%$ and Srilankan $31.8 \%$ respectively followed by Indian $19.3 \%$ and Maldivian were

Table 1: Socio demographic factors and energy drink consumption by medical students

\begin{tabular}{|c|c|c|c|c|}
\hline \multicolumn{3}{|c|}{$\begin{array}{c}\text { Socio demographic factors and energy } \\
\text { drink consumption } \\
\text { Factors }\end{array}$} & $P$ value & $95 \% \mathrm{Cl}$ \\
\hline \multirow{2}{*}{ Gender } & Female & $37(42)$ & \multirow{2}{*}{$0.033^{\dagger}$} & $(31.6,53)$ \\
\hline & Male & $51(58)$ & & $(47,68.4)$ \\
\hline \multirow[t]{4}{*}{ Nationality } & Maldivian & $12(13.6)$ & \multirow{4}{*}{ - } & $(7.2,22.6)$ \\
\hline & Srilankan & $28(31.8)$ & & $(22.3,42.6)$ \\
\hline & Indian & $17(19.3)$ & & $(11.7,29.1)$ \\
\hline & Nepalese & $31(35.2)$ & & $(25.3,46.1)$ \\
\hline \multirow[t]{2}{*}{ Level } & $1^{\text {st }}$ Year & $18(20.5)$ & \multirow[b]{2}{*}{$0.0001+$} & $(12.6,30.4)$ \\
\hline & $2^{\text {nd }}$ Year & $70(79.5)$ & & $(69.6,87.4)$ \\
\hline \multirow[t]{2}{*}{ Alcoholic } & Yes & $14(15.9)$ & \multirow[t]{2}{*}{$0.0001+$} & $(9,25.2)$ \\
\hline & No & $74(84.1)$ & & $(74.8,91)$ \\
\hline \multirow[t]{2}{*}{ Smoker } & Yes & $6(6.8)$ & \multirow{2}{*}{$0.0001+$} & $(2.5,14.3)$ \\
\hline & No & $82(93.2)$ & & $(85.7,97.5)$ \\
\hline \multirow{2}{*}{$\begin{array}{c}\text { Consumpti } \\
\text { on number } \\
\text { of cans/ } \\
\text { week }\end{array}$} & $\begin{array}{l}>5 \text { cans/we } \\
\text { ek }\end{array}$ & $25(28.4)$ & \multirow{2}{*}{$0.0001^{\dagger}$} & $(19.3,39)$ \\
\hline & $\begin{array}{l}<5 \\
\text { cans/week }\end{array}$ & $63(71.6)$ & & $(61,80.7)$ \\
\hline
\end{tabular}

$+p<0.05$, statistically significant

$\times p>0.05$, statistically not significant

Most of the students felt energetic after consuming energy drink 54/88. Insomnia was the most second common CNS manifestation which was found in 38 students out of 88 . Among all female students who consumed energy drink $45.9 \%$ and $41.2 \%$ males among all males students got insomnia. Other CNS manifestations were euphoria, Anxiety, dizziness, prolonged sleep, hallucination, headache and seizure disorder. Students who consumed $<5$ cans/week the commonest clinical features were felling energetic and insomnia. Most of the students suffered from palpitation among the CVS manifestations. Other GIT and CVS Manifestations were discomfort, nausea, vomiting, diarrhoea, abdominal pain, constipation, weight loss and chest pain. Students who consumed more than 5 cans/ week, constipation and palpitation were the two major health hazards. Among the students who consumed $<5$ cans / week generalized discomfort was the most common clinical feature. 
Table -2: CNS, GIT, CVS, ANS and Miscellaneous Manifestations of Energy drink consumption

\begin{tabular}{|c|c|c|c|c|c|c|c|c|c|c|}
\hline \multicolumn{2}{|c|}{ Risk factors } & \multicolumn{9}{|c|}{ CNS Manifestations } \\
\hline & & $\begin{array}{c}\text { Dizzines } \\
s \\
(N=10)\end{array}$ & $\begin{array}{c}\text { Energ } \\
\text { etic } \\
(\mathrm{N}=54 \\
)\end{array}$ & $\begin{array}{l}\text { Euphor } \\
\text { ia } \\
(\mathrm{N}=15)\end{array}$ & $\begin{array}{c}\text { Headach } \\
e \\
(\mathrm{~N}=9)\end{array}$ & $\begin{array}{c}\text { Insomn } \\
\text { ia } \\
(\mathrm{N}=38)\end{array}$ & $\begin{array}{c}\text { Prolon } \\
\text { ged } \\
\text { Sleep } \\
(\mathrm{N}=7)\end{array}$ & $\begin{array}{l}\text { Hallucination } \\
\qquad(N=6)\end{array}$ & $\begin{array}{l}\text { Anxiety } \\
(\mathrm{N}=14)\end{array}$ & $\begin{array}{l}\text { Seizure } \\
(\mathrm{N}=2)\end{array}$ \\
\hline \multirow[t]{3}{*}{ Gender } & Female & $1(2.7)$ & $\begin{array}{c}20 \\
(54.1)\end{array}$ & $6(16.2)$ & $5(13.5)$ & $\begin{array}{c}17 \\
(45.9)\end{array}$ & $2(5.4)$ & $2(5.4)$ & $6(16.2)$ & $0(0)$ \\
\hline & Male & $9(17.6)$ & $\begin{array}{c}34 \\
(66.7)\end{array}$ & $9(17.6)$ & $4(7.8)$ & $\begin{array}{c}21 \\
(41.2)\end{array}$ & $5(9.8)$ & $4(7.8)$ & $8(15.7)$ & 2(3.9) \\
\hline & $P$ value & $0.029+$ & $0.23^{x}$ & $0.86^{\mathrm{x}}$ & $0.38^{x}$ & $0.65^{x}$ & $0.452^{x}$ & $0.65^{x}$ & $0.94^{x}$ & $0.22^{x}$ \\
\hline \multirow[t]{3}{*}{$\begin{array}{c}\text { Number } \\
\text { of Cans/ } \\
\text { week }\end{array}$} & $\begin{array}{c}>5 \\
\text { Cans/wee } \\
\text { k }\end{array}$ & $2(8)$ & $\begin{array}{c}16 \\
(64)\end{array}$ & $5(20)$ & $0(0)$ & $\begin{array}{c}11 \\
(44)\end{array}$ & $5(20)$ & $3(12)$ & $5(20)$ & $1(4)$ \\
\hline & $\begin{array}{c}<5 \\
\text { Cans/wee } \\
\text { k }\end{array}$ & $8(12.7)$ & $\begin{array}{c}38 \\
(60.3)\end{array}$ & $\begin{array}{c}10 \\
(15.9)\end{array}$ & $9(14.3)$ & $\begin{array}{c}27 \\
(42.9)\end{array}$ & $2(3.2)$ & $3(4.8)$ & $9(14.3)$ & $1(1.6)$ \\
\hline & $P$ value & $0.531^{x}$ & 0.749 & $0.642^{x}$ & $0.046+$ & $0.922^{x}$ & $0.009+$ & $0.224^{x}$ & $0.509^{x}$ & $0.493^{x}$ \\
\hline \multirow{2}{*}{\multicolumn{2}{|c|}{ Risk factors }} & \multicolumn{9}{|c|}{ GIT and CVS Manifestations } \\
\hline & & $\begin{array}{l}\text { Nausea } \\
(n=10)\end{array}$ & $\begin{array}{c}\text { Vomit } \\
\text { ing } \\
(n=4)\end{array}$ & $\begin{array}{c}\text { Diarrho } \\
\quad \text { ea } \\
(n=4)\end{array}$ & $\begin{array}{c}\text { Abdomin } \\
\text { al } \\
\text { Pain }(n=5)\end{array}$ & $\begin{array}{l}\text { Constip } \\
\text { ation } \\
(n=9)\end{array}$ & $\begin{array}{c}\text { Weight } \\
\text { Loss } \\
(n=7)\end{array}$ & $\begin{array}{c}\text { Discomfort } \\
(\mathrm{N}=15)\end{array}$ & $\begin{array}{l}\text { Chest Pain } \\
\qquad(\mathrm{N}=3)\end{array}$ & $\begin{array}{l}\text { Palpitation } \\
\quad(n=15)\end{array}$ \\
\hline \multirow[t]{3}{*}{ Gender } & Female & $4(10.8)$ & $2(5.4)$ & $4(10.8)$ & $3(8.1)$ & $5(13.5)$ & $1(2.7)$ & $4(10.8)$ & $1(2.7)$ & $5(13.5)$ \\
\hline & Male & $6(11.8)$ & $2(3.9)$ & $0(0)$ & $2(3.9)$ & $4(7.8)$ & $6(11.8)$ & $11(21.6)$ & $2(3.9)$ & 10(19.6) \\
\hline & P Value & $0.88^{x}$ & $0.74^{x}$ & $0.016^{+}$ & $0.40^{x}$ & $0.38^{x}$ & $0.12^{x}$ & $0.185^{x}$ & $0.75^{x}$ & $0.45^{x}$ \\
\hline \multirow{3}{*}{$\begin{array}{c}\text { Number } \\
\text { of Cans/ } \\
\text { week }\end{array}$} & $\begin{array}{c}>5 \\
\text { Cans/wee }\end{array}$ & $2(8)$ & $2(8)$ & $2(8)$ & $1(4)$ & $5(20)$ & $3(12)$ & $4(16)$ & $1(4)$ & $5(20)$ \\
\hline & $\begin{array}{c}<5 \\
\text { Cans/wee }\end{array}$ & $8(12.7)$ & $2(3.2)$ & $2(3.2)$ & $4(6.3)$ & $4(6.3)$ & $4(6.3)$ & $11(17.5)$ & $2(3.2)$ & 10(15.9) \\
\hline & P Value & $0.531^{x}$ & $\underset{x}{0.327}$ & $0.327^{x}$ & $0.668^{x}$ & $0.057^{x}$ & $0.377^{x}$ & $0.869^{x}$ & $0.847^{x}$ & $0.642^{x}$ \\
\hline \multirow{2}{*}{\multicolumn{2}{|c|}{ Risk factors }} & \multicolumn{9}{|c|}{ ANS and Miscellaneous Manifestations } \\
\hline & & $\begin{array}{l}\text { Dry } \\
\text { mouth } \\
(n=17)\end{array}$ & $\begin{array}{l}\text { Sweat } \\
\text { ing } \\
(n=9)\end{array}$ & $\begin{array}{l}\text { Mictur } \\
\text { ation } \\
(\mathrm{n}=26)\end{array}$ & $\begin{array}{c}\text { Breathles } \\
\text { sness } \\
(n=3)\end{array}$ & $\begin{array}{c}\text { Allergic } \\
\text { reactio } \\
\text { ns } \\
(n=7)\end{array}$ & $\begin{array}{c}\text { Burning } \\
\text { sensation } \\
\text { of Throat } \\
(n=12)\end{array}$ & $\begin{array}{c}\text { Increased } \\
\text { stamina } \\
(n=39)\end{array}$ & $\begin{array}{c}\text { Taste good } \\
(n=14)\end{array}$ & \\
\hline \multirow[t]{3}{*}{ Gender } & Female & $8(21.6)$ & $2(5.4)$ & $10(27)$ & $1(2.7)$ & $2(5.4)$ & $2(5.4)$ & 19(51.4) & $9(24.3)$ & \\
\hline & Male & $9(17.6)$ & $\begin{array}{c}7 \\
(13.7)\end{array}$ & $\begin{array}{c}16 \\
(31.4)\end{array}$ & $2(3.9)$ & $5(9.8)$ & 10(19.6) & $20(39.2)$ & $5(9.8)$ & \\
\hline & $P$ value & $0.64^{x}$ & $0.20^{x}$ & $0.65^{x}$ & $0.75^{x}$ & $0.45^{x}$ & $0.055^{x}$ & $0.25^{x}$ & $0.066+$ & \\
\hline \multirow{3}{*}{$\begin{array}{c}\text { Number } \\
\text { of Cans/ } \\
\text { week }\end{array}$} & $\begin{array}{c}>5 \\
\text { Cans/wee }\end{array}$ & $4(16)$ & $5(20)$ & $8(32)$ & $2(8)$ & $3(12)$ & $5(20)$ & $11(44)$ & $2(8)$ & \\
\hline & $\begin{array}{c}<5 \\
\text { Cans/wee }\end{array}$ & $13(20.6)$ & $4(6.3)$ & $\begin{array}{c}18 \\
(28.6)\end{array}$ & $1(1.6)$ & $4(6.3)$ & $7(11.1)$ & $28(44.4)$ & $12(19)$ & \\
\hline & $P$ value & $0.619^{x}$ & $\underset{x}{0.057}$ & $0.751^{x}$ & $0.135^{x}$ & $0.377^{x}$ & $0.273^{x}$ & $0.970^{x}$ & $0.201^{x}$ & \\
\hline
\end{tabular}

$+p<0.05$, statistically significant

$x p>0.05$, statistically not significant

Nepal Journal of Epidemiology 2015;5(1):444-50

Copyright (C) 2015 CEA\& INEA

Published online by NepJOL-INASP

www.nepjol.info/index.php/NJE 
Table 3: Logistic Regression Model

\begin{tabular}{|c|c|c|c|c|c|c|c|c|c|c|}
\hline \multirow{2}{*}{\multicolumn{2}{|c|}{ Risk factors }} & \multicolumn{9}{|c|}{ CNS Manifestations } \\
\hline & & Dizziness & $\begin{array}{l}\text { Energet } \\
\text { ic }\end{array}$ & Euphoria & $\begin{array}{c}\text { Headach } \\
\mathrm{e}\end{array}$ & $\begin{array}{l}\text { Insomn } \\
\text { ia }\end{array}$ & $\begin{array}{l}\text { Prolonged } \\
\text { Sleep }\end{array}$ & $\begin{array}{l}\text { Hallucina } \\
\text { tion }\end{array}$ & Anxiety & Seizure \\
\hline \multirow[t]{2}{*}{ Gender } & Female & 1 & 1 & 1 & 1 & 1 & 1 & 1 & 1 & 1 \\
\hline & Male & $\begin{array}{c}0.139 \\
(0.016 \\
1.073) \times\end{array}$ & $\begin{array}{c}0.588(. \\
246 \\
1.404) \times\end{array}$ & $\begin{array}{l}0.903( \\
0.291 \\
2.803) \times\end{array}$ & $\begin{array}{c}1.836( \\
0.458 \\
7.367) \times\end{array}$ & $\begin{array}{c}1.214( \\
0.517 \\
2.852) \times\end{array}$ & $\begin{array}{c}0.526( \\
0.096 \\
2.871) \times\end{array}$ & $\begin{array}{c}0.656( \\
.116 \\
3.875) \times\end{array}$ & $\begin{array}{c}1.040( \\
0.328 \\
3.302) \times\end{array}$ & - \\
\hline \multirow{2}{*}{\multicolumn{2}{|c|}{$\begin{array}{c}\text { GIT and CVS } \\
\text { Manifestations }\end{array}$}} & \multicolumn{9}{|c|}{ GIT and GIT Manifestations } \\
\hline & & Nausea & $\begin{array}{l}\text { Vomiti } \\
\text { ng }\end{array}$ & $\begin{array}{c}\text { Diarrhoe } \\
\text { a }\end{array}$ & $\begin{array}{l}\text { Abdomin } \\
\text { al Pain( }\end{array}$ & $\begin{array}{l}\text { Constip } \\
\text { ation }\end{array}$ & $\begin{array}{l}\text { Weight } \\
\text { Loss }\end{array}$ & $\begin{array}{c}\text { Discomfo } \\
\mathrm{rt}\end{array}$ & Chest Pain & Palpitation \\
\hline \multirow[t]{2}{*}{ Gender } & Female & 1 & 1 & 1 & 1 & 1 & 1 & 1 & 1 & 1 \\
\hline & Male & $\begin{array}{l}0.909( \\
0.237 \\
3.481) \times\end{array}$ & $\begin{array}{c}1.4( \\
0.188 \\
10.421)\end{array}$ & - & $\begin{array}{c}2.162( \\
0.343 \\
13.638) \times\end{array}$ & $\begin{array}{l}1.836( \\
0.458 \\
7.367)\end{array}$ & $\begin{array}{c}0.208( \\
0.024 \\
1.810) \times\end{array}$ & $\begin{array}{c}0.441( \\
0.128 \\
1.514) \times\end{array}$ & $\begin{array}{c}0.681( \\
0.059 \\
7.798) \times\end{array}$ & $\begin{array}{c}0.641(0.199 \\
2.062) \times\end{array}$ \\
\hline \multirow{2}{*}{\multicolumn{2}{|c|}{$\begin{array}{c}\text { ANS and } \\
\text { Miscellaneous } \\
\text { Manifestations }\end{array}$}} & \multicolumn{9}{|c|}{ ANS and Miscellaneous } \\
\hline & & $\begin{array}{c}\text { Dry } \\
\text { mouth }\end{array}$ & $\begin{array}{c}\text { Sweati } \\
\text { ng }\end{array}$ & $\begin{array}{l}\text { Micturat } \\
\text { ion }\end{array}$ & $\begin{array}{l}\text { Breathle } \\
\text { ssness }\end{array}$ & $\begin{array}{c}\text { Allergic } \\
\text { reactio } \\
\text { ns }\end{array}$ & $\begin{array}{l}\text { Burning } \\
\text { sensation } \\
\text { of Throat }\end{array}$ & $\begin{array}{c}\text { Increased } \\
\text { stamina }\end{array}$ & Taste good & \\
\hline \multirow[t]{2}{*}{ Gender } & Female & 1 & 1 & 1 & 1 & 1 & 1 & 1 & 1 & \\
\hline & Male & $\begin{array}{l}1.287( \\
0.444 \\
3.729) \times\end{array}$ & $\begin{array}{l}0.359( \\
0.07,1 \\
839) \times\end{array}$ & $\begin{array}{c}0.81( \\
0.318 \\
2.066) \times\end{array}$ & $\begin{array}{c}0.681( \\
0.059,7 \\
798) \times\end{array}$ & $\begin{array}{l}0.526( \\
0.096 \\
2.871)\end{array}$ & $\begin{array}{c}0.234( \\
0.048 \\
1.142) \times\end{array}$ & $\begin{array}{c}1.636( \\
0.696 \\
3.848) \times\end{array}$ & $\begin{array}{c}2.957(0.9 \\
9.719) \times\end{array}$ & \\
\hline
\end{tabular}

$x p>0.05$, statistically not significant

$-P$ value- cannot calculate 
ANS and miscellaneous manifestations were also seen among the students among which increased stamina 39/88 was the most common feature followed by increased micturation 26/ 88, dry mouth, sweating, burning sensation in the throat, allergic reactions, breathlessness were noted by the students ( Table 2 ).

Determinants of different clinical manifestations and energy drink consumption by logistic regression.

Logistic regression analysis finding shows that the CNS manifestations, viz. Headache and insomnia was found more prevalent in males [OR $1.83695 \%(\mathrm{Cl} 0.458,7.367)$ ] and [OR 1.214, $95 \%(\mathrm{Cl} 0.517,2.852)]$, respectively as compared to female students. However, in the case of GIT manifestations viz. abdominal pain and constipation it was was more prevalent among male students [OR 2.292, 95 $\%(\mathrm{Cl}(0.343,13.638)]$ and $[\mathrm{OR} 1.836,95 \%(\mathrm{Cl} 0.458,7.367)]$ respectively as compared to females. Among the ANS manifestations dry mouth [OR 1.287, 95\% (Cl $(0.444,3.729)$ ] was more prevalent among male students (Table 3 ).

\section{Discussion:}

\section{Socio demographic factors and energy drink consumption:}

The research finding revealed that most of the students who consumed energy drink were males. Similar findings were found in Australia $^{8}$. Most of the students were Nepalese and Srilankan by Nationality. It was found that the students who were in the $2^{\text {nd }}$ year consumed more amount of energy drink as compared to the $1^{\text {st }}$ year students. Around $16 \%$ of the students were found to be alcoholic. In a study conducted by Bigard AX, it was found that teenagers and students takes alcohol and energy drink to socialize and to meet people. Alcohol with energy drink may produce serious injury, sexual assault, drunk driving, and even death. Thus it should be strictly controlled subjective perceptions of some features of alcohol intoxication are less intense after the intake of the alcohol along with energy drink ${ }^{9,10}$.

\section{CNS manifestations and energy drink consumption:}

Most of the students felt energetic after consuming energy drink. Insomnia was the second most common CNS manifestation. Similar findings were found by Malinauskas $\mathrm{BM}$ et al at Central Atlantic region of the United States. The primary component in energy drinks that has a cognitive enhancing effect is the caffeine whereas high sugar content does not improve reaction times slowed by sleep deprivation $^{11}$. Other CNS manifestations were euphoria, Anxiety, dizziness, prolonged sleep, hallucination, headache and seizure disorder. This is in parallel to the findings by Malinauskas BM et al $^{11}$ and Raviv B et $\mathrm{al}^{1}$.

GIT and CVS manifestations and energy drink consumption:

Most of the students suffered from palpitation among the CVS manifestations. Other GIT and CVS Manifestations were discomfort, nausea, vomiting, diarrhoea, abdominal pain, constipation, weight loss and chest pain. Similar findings were reported by Malinauskas $\mathrm{BM}^{11}$. Our findings are also parallel to the finding of a study done in Australia by ${ }^{8}$ Gunja $\mathrm{N}$ et al which has also reported that cardiovascular and gastrointestinal effects like palpitations, agitation, tremor and gastrointestinal upset were seen with the energy drink.

\section{ANS, Miscellaneous manifestations and energy drink} consumption:

ANS and miscellaneous manifestations were also seen among the students among which increased stamina was the most common feature followed by increased micturation, dry mouth, sweating, burning sensation in the throat, allergic reactions, breathlessness were noted by the students. Similar findings were reported by Lee SE et al like generalized itching, urticaria, dyspnea and dizziness after drinking taurine containing drinks ${ }^{12}$.

\section{Conclusion}

It is concluded that energy drink gives energy and increases the stamina but it produces neurologic, psychiatric, cardiovascular and gastrointestinal complications on health. Further studies are required on the same field to find out its effect on health in Nepalese population.

\section{Limitation of the study}

The sample size of the study was less. A multi centric study with higher sample size will give better idea of the effect of energy drink on the health.

\section{Future scope of the study:}

This study is based on the research carried out in a medical school in Nepal. A multi centric based research with high sample size would be beneficial to assess the effects of the energy drink on the health of individual.

\section{Author's Contribution:}

IB designed the study, drafted the manuscript and revised it. PB collected the data along with IB. IB2 and PB has participated in the language editing along with PRN. BS participated in statistical analysis, interpreted the data, and revised the manuscript. PRN and BR critically revised the manuscript. All the authors approved the final document.

\section{Acknowledgements:}

The authors are thankful to Dr. B.M. Nagpal, Dean of Manipal College of Medical Sciences, Pokhara, Nepal, Dr. Shishir Gokhale, Director of Basic Sciences, Manipal College of Medical Sciences, Pokhara, Nepal for constant encouragement and support. The authors are thankful to Dr. R.K.Sharma, Dean, Padmashree Dr.D.Y.Patil Medical College, Mauritius for great support and immense help for conducting this research work. The authors are also grateful to Dr. Subhash L Bodhankar, Chairman, Institutional Research Committee and Professor, Department of Pharmacology, Padmashree Dr.D.Y.Patil Medical College, Mauritius for conducting the research work. We are also thankful to Mr. Bipashwi Nath Uprety, Tutor, Department of Pharmacology, Padmashree Dr.D.Y.Patil Medical College, Mauritius for constant support. 


\section{Energy drink consumption among medical students}

\section{Conflict of interest:}

There is no conflict of interest among authors arising from the study.

\section{What does this study adds}

Energy drink produces autonomic, neurologic, psychiatric, cardiovascular and gastrointestinal complications on health of individuals. This is first study reported on the effects of energy drink on the health of medical students from Nepal.

\section{List of abbreviations}

ANS- Autonomic nervous system

CNS- Central nervous system

CVS- Cardiovascular system

GIT- Gastrointestinal system

\section{Declaration:}

This paper got the best paper award in the International conference of research methodology and scientific writing, ICRMSW 2013, Kerala, India.

\section{References:}

1. Raviv B, Zaidani H, Israelit SH. Health hazards of energy drinks--the situation in Israel and the world. Harefuah. 2014 Mar-Apr;153(3-4):176-9, 238.

PMid:24791560

2. Clauson KA1, Shields KM, McQueen CE, Persad N. Safety issues associated with commercially available energy drinks. J Am Pharm Assoc (2003). 2008 May-Jun;48(3):e5563; quiz e64-7. doi: 10.1331/JAPhA.2008.07055. http://dx.doi.org/10.1331/JAPhA.2008.07055

3. Naeem Z. Health hazards of Energy Drinks and positive actions by Saudi Government. int J Health Sci (Qassim). 2014 Apr;8(2):V-VI

PMiD:25246888

4. Petit A, Levy F, Lejoyeux M, Reynaud M, Karila L. Energy drinks: an unknown risk. Rev Prat. 2012 May;62(5):673-8. PMid:22730801

5. Breda JJ, Whiting SH, Encarnação R, Norberg S, Jones R, Reinap $M$, Jewell J. Energy drink consumption in europe: a review of the risks, adverse health effects, and policy options to respond. Front Public Health. 2014 Oct 14;2:134. doi: 10.3389/fpubh.2014.00134. eCollection 2014. http://dx.doi.org/10.3389/fpubh.2014.00134

6. Sathian B, Sreedharan J, Baboo NS, Sharan K, Abhilash E $\mathrm{S}$, Rajesh E. Relevance of Sample Size Determination in Medical Research. Nepal Journal of Epidemiology 2010;
1(1): 4-10.

http://dx.doi.org/10.3126/nje.v1i1.4100

7. WMA Declaration of Helsinki - Ethical Principles for Medical Research Involving Human Subjects.64th WMA General Assembly, Fortaleza, Brazil, October 2013. [online] 2013 [cited 2015 Feb 20]. Available from:

http://www.wma.net/en/30publications/10policies/b3/

8. Gunja N1, Brown JA. Energy drinks: health risks and toxicity. Med J Aust. 2012 Jan 16;196(1):46-9.

PMid:22256934

9. Bigard AX. Risks of energy drinks in youths. Arch Pediatr. 2010 Nov;17(11):1625-31. doi: 10.1016/j.arcped.2010.08.001. http://dx.doi.org/10.1016/j.arcped.2010.08.001

10. Pennay, A.E. and Lubman, D.I. Energy drinks: health risks and toxicity. Med J Aust. 2012; 196: 442 http://dx.doi.org/10.5694/mja12.10211

PMid:22509868

11. Malinauskas BM1, Aeby VG, Overton RF, CarpenterAeby T, Barber-Heidal K. A survey of energy drink consumption patterns among college students. Nutr J. 2007 Oct 31;6:35.

http://dx.doi.org/10.1186/1475-2891-6-35 PMid:17974021 PMCid:PMC2206048

12. Lee SE, Lee SY, Jo EJ, Kim MY, Yang MS, Chang YS, Kim $\mathrm{SH}$. A case of taurine-containing drink induced anaphylaxis. Asia Pac Allergy. 2013 Jan;3(1):70-3. doi: 10.5415/apallergy.2013.3.1.70. Epub 2013 Jan 30. http://dx.doi.org/10.5415/apallergy.2013.3.1.70

\section{Article Information}

\section{Article history}

\begin{tabular}{|l|c|}
\hline Received & $2^{\text {nd }}$ October 2014 \\
\hline Received in revised form & $4^{\text {th }}$ March 2015 \\
\hline Accepted & $24^{\text {th }}$ March 2015 \\
\hline
\end{tabular}

